Iwona Sierocka

Uniwersytet $w$ Biatymstoku

\title{
WYNAGRODZENIE PRACOWNIKÓW PARKÓW NARODOWYCH
}

\section{Wprowadzenie}

Ochrona przyrody pojmowana jako troska o zachowanie oraz zrównoważone korzystanie z zasobów środowiska naturalnego ${ }^{1}$ jest jednym z podstawowych wyzwań współczesnego świata. Podejmowane są różnorodne działania zarówno na szczeblu międzynarodowym, jak i poszczególnych państw, których celem jest zachowanie wszystkich składników środowiska naturalnego w jak najlepszym stanie. Wśród rozwiązań o zasięgu ponadnarodowym służących ochronie przyrody wymienić należy Konwencję o ochronie gatunków dzikiej flory i fauny oraz ich siedlisk (tzw. konwencja berneńska) z 1979 r., ${ }^{2}$ Konwencję o międzynarodowym handlu dzikimi zwierzętami i roślinami gatunków zagrożonych wyginięciem z 1973 r. ${ }^{3}$ W obrębie Unii Europejskiej zagadnieniom związanym z ochroną środowiska poświęconych jest szereg rozporządzeń, decyzji, dyrektyw i zaleceń oraz innych dokumentów programowych ważnych z punktu widzenia polityki ekologicznej państw unijnych. ${ }^{4}$ Spośród tego rodzaju przepisów wymienić należy rozporządzenie Rady (WE) nr 338/97 z 1996 r. w sprawie ochrony gatunków dzikiej fauny i flory w drodze regulacji handlu nimi ${ }^{5}$ oraz rozporządzenie Komisji (WE) nr 865/2006 z 2006 r. ustanawiające przepisy wykonawcze do rozporządzenia Rady (WE) nr 338/97 z 2006 r. w sprawie ochrony gatunków dzikiej fauny i flory w drodze regulacji handlu nimi, ${ }^{6}$ dyrektywę Rady 92/43/EWG z dnia 21 maja 1992 r. w sprawie ochrony siedlisk

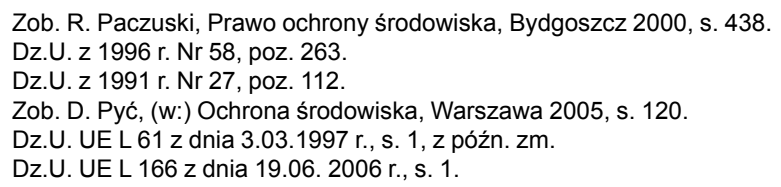


przyrodniczych oraz dzikiej fauny i flory, ${ }^{7}$ dyrektywę Rady 1999/22/WE z 1999 r. dotyczącą trzymania dzikich zwierząt w ogrodach zoologicznych, ${ }^{8}$ dyrektywę Parlamentu Europejskiego i Rady 2009/147/WE z dnia 30 listopada 2009 r. w sprawie ochrony dzikiego ptactwa (wersja ujednolicona). ${ }^{9}$

Potrzebę ochrony przyrody dostrzeżono także w Polsce wydając w tym celu stosowne przepisy..$^{10}$ Obecnie zagadnienia związane z zachowaniem środowiska naturalnego reguluje ustawa $\mathrm{z}$ dnia 16 kwietnia 2004 r. o ochronie przyrody. ${ }^{11}$

Zgodnie z art. 2 tej ustawy ochrona przyrody służy w szczególności: utrzymaniu procesów ekologicznych i stabilności ekosystemów; zachowaniu różnorodności biologicznej; zachowaniu dziedzictwa geologicznego i paleontologicznego; zapewnieniu ciągłości istnienia gatunków roślin, zwierząt, wraz z ich siedliskami, przez ich utrzymywanie lub przywracanie do właściwego stanu ochrony. Ochrona przyrody realizowana jest $\mathrm{w}$ różnych formach. Ustanawia się rezerwaty przyrody, parki krajobrazowe, obszary chronionego krajobrazu, obszary Natura 2000. Podstawową rolę w tym względzie odgrywają parki narodowe. Należyte wypełnianie zadań stojących przed nimi wymaga zatrudniania odpowiednio przygotowanej i wykwalifikowanej kadry pracowników.

Spośród zagadnień wiążących się z prawami i obowiązkami osób świadczących pracę $\mathrm{w}$ parkach narodowych zagadnieniem o podstawowym znaczeniu jest kwestia wynagrodzeń. Zgodnie z art. $77^{1}$ k.p. warunki wynagradzania za pracę i przyznawania innych świadczeń związanych z pracą co do zasady ustalają układy zbiorowe pracy. W odniesieniu do wskazanych osób kluczowe znaczenie ma zawarty w 2013 r. Ponadzakładowy Układ Zbiorowy Pracy dla Pracowników Parków Narodowych. ${ }^{12} \mathrm{~W}$ dalszej części rozważania będą się koncentrowały wokół postanowień wskazanego układu zbiorowego pracy.

\section{Wynagrodzenie zasadnicze}

Wynagrodzenie za pracę jest jednym z podstawowych uprawnień przysługujących pracownikom z tytułu należytego wykonywania obowiązków, które wynikają ze stosunku pracy. Składa się ono z wynagrodzenia zasadniczego oraz składników dodatkowych, wśród których w układzie wymienia się: dodatek za pracę w szczególnych warunkach, dodatek stażowy, premie oraz nagrody jubileuszowe.

7 Dz. Urz. UE L 206 z dnia 22.07.1992, s. 7, z późn. zm.; Dz. Urz. UE Polskie wydanie specjalne, rozdz. 15, t. 2, s. 102 , z późn. zm.

$8 \quad$ Dz. Urz. UE L 94 z dnia 9.04.1999 r., s. 24.

9 Dz. Urz. UE L 20 z dnia 26.01.2010 r., s. 7.

10 Pierwszym aktem prawnym w tym zakresie była ustawa z dnia 10 marca 1934 r. o ochronie przyrody (Dz.U. RP $\mathrm{Nr} 31$, poz. 274), następnie zostały uchwalone: ustawa z dnia 7 kwietnia 1949 r. o ochronie przyrody (Dz.U. Nr 25, poz. 180 z późn. zm.) oraz ustawa z dnia 16 października 1991 r. o ochronie przyrody (t.j. Dz.U. z 2001 r. Nr 99 , poz. 1079 z późn. zm.).

11 T.j. Dz.U. z 2013 r., poz. 627.

12 Dalej jako „układ” lub p.u.z.p. 
W literaturze przedmiotu rozróżnia się wynagrodzenie sensu stricto przysługujące z tytułu wykonanej pracy oraz sensu largo. To ostatnie oprócz wynagrodzenia w ścisłym tego słowa znaczeniu obejmuje tzw. wypłaty gwarancyjne, do których zalicza się świadczenia pieniężne przysługujące pracownikowi za okresy niewykonywania pracy. Wśród nich wymienia się m.in. wynagrodzenie: za czas choroby, za czas przestoju, za urlop wypoczynkowy. ${ }^{13}$

Wynagrodzenie zasadnicze stanowi stały i obligatoryjny składnik wynagrodzenia. W układzie ponadzakładowym przyjęto, że dla pracowników Służby Parku Narodowego, zatrudnionych na stanowiskach pomocniczych i obsługi wynagrodzenie zasadnicze ustala się w oparciu o metodę czasową. W odniesieniu do osób świadczących pracę na stanowiskach robotniczych stosuje się cztery systemy wynagradzania, mianowicie a) czasowy, b) czasowo-premiowy, c) akordowy oraz d) czasowo-akordowy. W tym ostatnim przypadku pracownik otrzymuje wynagrodzenie w zależności od stawki osobistego zaszeregowania do momentu osiągnięcia określonego poziomu efektywności. Po jego przekroczeniu wynagradzany jest przy zastosowaniu systemu akordowego. W systemie czasowo-premiowym wynagrodzenie uzależnione jest od kategorii zaszeregowania oraz premii wypłacanych z tytułu wykonywania określonych zadań.

W parkach narodowych objętych omawianym układem przewidziano 20 kategorii zaszeregowania. Wynagrodzenie zasadnicze kształtuje się od $1100 \mathrm{zł} \mathrm{w}$ pierwszej kategorii do 8 tysięcy złotych w kategorii ostatniej.

\section{Dodatkowe składniki wynagrodzenia}

Pracownicy zatrudnieni w warunkach uciążliwych dla zdrowia lub niebezpiecznych uprawnieni są do dodatku, którego wysokość uzależniona jest od stopnia uciążliwości lub szkodliwości. W p.u.z.p. przewiduje się cztery stopnie uciążliwości lub szkodliwości (od I do IV). Kwota dodatku wynosi odpowiednio: do 5\%, do 10\%, do $15 \%$ oraz do $20 \%$ stawki godzinowej wynikającej z minimalnego wynagrodzenia. Dodatek przysługuje za każdą godzinę pracy wykonywanej w warunkach szkodliwych lub uciążliwych. W układzie zawarto szczegółowy wykaz prac zakwalifikowanych do poszczególnych stopni uciążliwości lub szkodliwości dla zdrowia oraz prac niebezpiecznych, wykonywanie których uprawnia do stosownego dodatku. Należy podkreślić, że wykaz prac wymienionych w załączniku $\mathrm{Nr} 4$ nie ma charakteru enumeratywnego. W myśl $\S 28$ ust. 3 p.u.z.p. pracodawca w oparciu o wyniki badań i pomiarów czynników szkodliwych dla zdrowia w środowisku pracy może w poro-

13 Zob. J. Jonczyk, Prawo pracy, Warszawa 1995, s. 356-357; B. Wagner, Wynagrodzenie za pracę. (Pojęcie, prawna ochrona i źródła regulacji), (w:) Studia z zakresu prawa pracy i polityki społecznej, A. Świątkowski (red.), Kraków 1986, s. 142; T. Zieliński, Prawo pracy. Zarys systemu. Część II. Prawo stosunku pracy, Warszawa-Kraków 1986, s. 283. 
zumieniu z zakładową organizacją związkową uznać inne prace za szkodliwe, uciążliwe lub niebezpieczne.

Pracownicy legitymujący się pięcioletnim okresem zatrudnienia uprawnieni są do dodatku za wysługę lat w wysokości $5 \%$ miesięcznego wynagrodzenia zasadniczego. W kolejnych latach dodatek ten wzrasta o $1 \%$, aż do osiągnięcia $20 \%$ miesięcznego wynagrodzenia zasadniczego po 20 i więcej latach pracy. W stażu upoważniającym do dodatku uwzględnia się wszystkie okresy zatrudnienia niezależnie od przerw w zatrudnieniu oraz sposobu ustania stosunku pracy, okresy prowadzenia działalności gospodarczej, a także inne okresy, jeżeli na mocy odrębnych przepisów podlegają one wliczeniu do okresu pracy, od którego zależą uprawnienia pracownicze. W przypadku tych ostatnich chodzi o okresy, w których pracownik ubiegający się o dodatek stażowy nie pozostawał faktycznie w stosunku pracy, podlegające wliczeniu do stażu zakładowego na podstawie przepisów powszechnie obowiązujących. Wśród okresów tzw. zaliczalnych wymienić należy w szczególności: a) okresy czynnej służby wojskowej (art. 301 k.p.), b) okresy wykonywania pracy w służbach mundurowych, np. Policji, Służbie Więziennej (art. 302 k.p.), c) okresy pobierania zasiłku dla bezrobotnych (art. 79 ust. 1 ustawy z dnia 20 kwietnia 2004 r. o promocji zatrudnienia $\mathrm{i}$ instytucjach rynku pracy, ${ }^{14} \mathrm{~d}$ ) okresy pracy $\mathrm{w}$ gospodarstwie rolnym (art. 1 ust. 1 pkt 1-3 ustawy z dnia 20 lipca 1990 r. o wliczaniu okresów pracy w indywidualnym gospodarstwie rolnym do pracowniczego stażu pracy ${ }^{15}$ ), e) okresy, za które pracownikowi przyznano odszkodowanie w związku z nieprawidłowym rozwiązaniem przez pracodawcę umowy o pracę (art. $51 \S 2$ i art. 61 k.p.)

W układzie zastrzega się, że w razie gdy praca w parku narodowym stanowi dodatkowe zatrudnienie, prawo do dodatku za wysługę lat ustala się odrębnie dla każdego stosunku pracy. Zaliczeniu do okresu dodatkowego zatrudnienia nie podlegają okresy zatrudnienia podstawowego ( $\$ 33$ ust. 3). Z treści cytowanego przepisu wynika, że w przypadku jednoczesnego pozostawania w dwóch lub więcej stosunkach pracy, do okresu zatrudnienia w parku narodowym wlicza się jedynie zakończone okresy zatrudnienia.

Zasadniczo dodatek stażowy przysługuje pracownikowi za dni, za które otrzymuje wynagrodzenie. $\mathrm{Z}$ uprawnienia $\mathrm{w}$ tym względzie korzysta także pracownik nieobecny w pracy z powodu niezdolności do pracy wskutek choroby bądź konieczności osobistego sprawowania opieki nad dzieckiem lub chorym członkiem rodziny, pobierający wynagrodzenie gwarancyjne lub zasiłek z ubezpieczenia społecznego.

Pracownicy objęci p.u.z.p. uprawnieni są także do premii. W tym zakresie układ jest bardzo lakoniczny. Przewiduje się jedynie, że w ramach środków na wynagrodzenia tworzy się fundusz premiowy w wysokości co najmniej 5\% wynagrodzeń zasadniczych z przeznaczeniem na premie motywacyjne dla pracowników. Szcze- 
gółowe zasady dotyczące przyznawania i wypłacania premii określa się w zakładowych regulaminach premiowania.

\section{Nagrody jubileuszowe}

Wśród dodatkowych składników wynagrodzenia przysługujących pracownikom parków narodowych w układzie przewiduje się nagrody jubileuszowe. W myśl $\S 31$ ust. 1 p.u.z.p. pracownikowi przysługuje nagroda jubileuszowa w wysokości:

a) po 20 latach pracy $-75 \%$ miesięcznego wynagrodzenia,

b) po 25 latach pracy $-100 \%$ miesięcznego wynagrodzenia,

c) po 30 latach pracy $-150 \%$ miesięcznego wynagrodzenia,

d) po 35 latach pracy $-200 \%$ miesięcznego wynagrodzenia,

e) po 40 latach pracy $-300 \%$ miesięcznego wynagrodzenia,

f) po 45 latach pracy $-400 \%$ miesięcznego wynagrodzenia,

g) po 50 latach pracy $-500 \%$ miesięcznego wynagrodzenia.

Przy ustalaniu okresów pracy wymaganych do nabycia prawa do nagrody jubileuszowej wlicza się wszystkie poprzednie zakończone okresy zatrudnienia oraz okresy prowadzenia działalności gospodarczej, a także inne okresy, jeżeli z mocy odrębnych przepisów podlegają one wliczeniu do okresu pracy, od którego zależą uprawnienia pracownicze. W razie równoczesnego pozostawania $\mathrm{w}$ więcej niż jednym stosunku pracy, do okresu pracy uprawniającego do nagrody jubileuszowej wlicza się tylko jeden z tych okresów, wybrany przez pracownika. W układzie zastrzega się ponadto, że z roszczeniem o wypłatę nagrody jubileuszowej może wystąpić pracownik, którego staż pracy w parkach narodowych, gospodarstwach pomocniczych parków narodowych lub Krajowym Zarządzie Parków Narodowych wynosi łącznie co najmniej 10 lat.

Z treści postanowień układowych wynika, że w stażu uprawniającym do nagrody jubileuszowej pracodawca zobowiązany jest uwzględnić: 1) okresy pracy w parkach narodowych, gospodarstwach pomocniczych parków narodowych oraz w Krajowym Zarządzie Parków Narodowych, 2) okresy świadczenia pracy na rzecz innych podmiotów, o ile uległy one zakończeniu, 3) okresy, w których dana osoba prowadziła działalność gospodarczą oraz 4) tzw. okresy zaliczalne.

W przypadku pracownika legitymującego się 50-letnim stażem wymaga się ponadto, aby okres uprawniający do nagrody jubileuszowej przypadał przed dniem spełnienia przez niego warunków do uzyskania świadczenia emerytalnego na zasadach ogólnych. Okres 50 lat powinien zatem przypadać przed dniem ukończenia wieku emerytalnego przewidzianego w art. 24 ustawy emerytalnej ${ }^{16}$ (w odniesieniu

16 Ustawa z dnia 17 grudnia 1998 r. o emeryturach i rentach z Funduszu Ubezpieczeń Społecznych, t.j. Dz.U. z 2013 r., poz. 1440 z późn. zm. 
do ubezpieczonych urodzonych po 31 grudnia 1948 r.) bądź spełniania warunków określonych $\mathrm{w}$ art. 27 ustawy emerytalnej (w przypadku ubezpieczonych urodzonych przed 1 stycznia 1949 r.). Należy podkreślić, że w $\S 31$ ust. 1 układu mowa jest o ,spełnieniu przez pracownika warunków do uzyskania świadczeń emerytalnych”, a nie o nabyciu prawa do emerytury. Chodzi zatem o spełnienie przesłanek przewidzianych w przepisach ubezpieczeniowych warunkujących nabycie prawa do emerytury. Bez znaczenia pozostaje kwestia, czy faktycznie do dnia ukończenia 50 lat pracy pracownik uzyskał decyzję ZUS stwierdzającą nabycie prawa do świadczenia emerytalnego.

Zastrzeżenie przewidziane w $\S 31$ ust. 1 p.u.z.p. dotyczy wyłącznie świadczeń emerytalnych na zasadach ogólnych. Pomija się zatem zarówno emerytury wcześniejsze, jak i emerytury pomostowe. W konsekwencji z żądaniem wypłaty nagrody jubileuszowej wystąpić może pracownik, który staż 50 lat osiągnie w okresie pobierania tego rodzaju emerytury.

Pracownik nabywa prawo do nagrody jubileuszowej w dniu upływu okresu uprawniającego do nagrody. ${ }^{17}$ Do jej wypłaty powinno dojść niezwłocznie po nabyciu przez pracownika prawa do tej nagrody, lecz nie później niż przy wypłacie najbliższego wynagrodzenia miesięcznego. Ustalając wysokość nagrody jubileuszowej pracodawca bierze pod uwagę wynagrodzenie przysługujące pracownikowi w dniu nabycia prawa do tego świadczenia, a jeżeli dla zatrudnionego jest to korzystniejsze - wynagrodzenie przysługujące mu w dniu wypłaty nagrody. Nagrodę oblicza się według zasad obowiązujących przy ustalaniu ekwiwalentu pieniężnego za urlop wypoczynkowy. ${ }^{18}$

W myśl $\S 31$ ust. 8 p.u.z.p. w razie ustania stosunku pracy w związku z przejściem na rentę $\mathrm{z}$ tytułu niezdolności do pracy lub na emeryturę pracownikowi, któremu do nabycia prawa do nagrody jubileuszowej brakuje mniej niż 12 miesięcy, licząc od dnia rozwiązania stosunku pracy, nagrodę wypłaca się w dniu rozwiązania stosunku pracy. Zasada ta nie ma zastosowania wobec pracowników ubiegających się o nagrodę z tytułu ukończenia 50 lat pracy. Innymi słowy, o wypłatę nagrody jubileuszowej w wysokości 500\% wynagrodzenia może ubiegać się wyłącznie pracownik, który do chwili ustania zatrudnienia osiągnął pełny wymagany staż.

$\mathrm{Na}$ tym tle nasuwa się pytanie, czy pozbawienie pracowników legitymujących się w dniu rozwiązania stosunku pracy, z powodu przejścia na emeryturę lub rentę z tytułu niezdolności do pracy, ponad 49-letnim stażem pracy nie ma znamion dyskryminacji.

Zważywszy, iż co do zasady nagroda jubileuszowa nie jest świadczeniem obligatoryjnym, strony układowe mają prawo dowolnego ustalania przesłanek warun-

17 Zob. wyrok SN z 21 grudnia 2004 r., I PK 114/04, „Prawo Pracy” 2005, nr 6, s. 29.

18 Rozporządzenie MPiPS z dnia 8 stycznia 1997 r. w sprawie szczegółowych zasad udzielania urlopu wypoczynkowego, ustalania i wypłacania wynagrodzenia za czas urlopu oraz ekwiwalentu pieniężnego za urlop, Dz.U. Nr 2, poz. 14 z późn. zm. 
kujących nabycie do niej prawa. Prezentowany wniosek znajduje potwierdzenie w wyroku Sądu Najwyższego z dnia 22 stycznia 2002 r., ${ }^{19}$ w którym Sąd ten stwierdził, że gratyfikacja jubileuszowa jest świadczeniem fakultatywnym i przepisy płacowe mogą kształtować do niej prawo w sposób samodzielny i swobodny. Wymaga się jednak respektowania zasady wyrażonej $\mathrm{w}$ art. $18^{3 \mathrm{c}} \mathrm{k} . \mathrm{p} .{ }^{20} \mathrm{~W}$ podobnym duchu wypowiedział się SN w wyroku z dnia 14 maja 2012 r., ${ }^{21}$ orzekając, że reguły kształtowania wynagrodzenia w przepisach (aktach) wewnątrzzakładowych muszą uwzględniać zawartą w Konstytucji oraz w kodeksie pracy zasadę równości oraz zakaz dyskryminacji.

Podmioty negocjujące układ zbiorowy pracy zobowiązane są do respektowania zasad przewidzianych w kodeksie pracy, wśród których wymienia się w szczególności zasadę uprzywilejowania pracowników (art. 9 § 2 k.p.) oraz zasadę równego traktowania w zatrudnieniu (art. $9 \S 4$ k.p.). ${ }^{22} \mathrm{~W}$ myśl przepisów kodeksowych mocy wiążącej pozbawione są postanowienia układowe, które spełniają kryteria przewidziane $\mathrm{w} \S 2$ (nie są mniej korzystne dla pracowników niż przepisy ustaw i aktów wykonawczych), ale jednocześnie naruszają zakazy dyskryminowania określone w art. $11^{2}, 11^{3}, 18^{3 a}-18^{3 e}$ k.p. Dotyczy to sytuacji, w której z rozszerzenia w układzie zbiorowym uprawnień lub ograniczenia obowiązków nie korzystają $w$ równym stopniu wszyscy pracownicy zatrudnieni u danego pracodawcy. Powstaje wątpliwość, czy w takim przypadku pracodawca zobowiązany jest do respektowania wobec całej załogi, w tym także pracowników, którym w układzie zbiorowym pracy rozszerzono przywileje lub ograniczono obciążenia, odpowiednich przepisów o charakterze powszechnie obowiązującym. W ocenie TSUE zasada równego traktowania umożliwia pracownikom traktowanym gorzej ubieganie się o określone świadczenia, których byli dotychczas pozbawieni. ${ }^{23}$ Podobne stanowisko zajmuje Trybunał Konstytucyjny. ${ }^{24}$

Użyty w art. 9 § 4 k.p. zwrot ,postanowienia układu zbiorowego pracy nie obowiązują" należy zatem rozumieć w ten sposób, że postanowienia te nie obowiązują $\mathrm{w}$ tym zakresie, w jakim pozbawiają określonych pracowników dodatkowych uprawnień. W konsekwencji postanowienia układowe rozszerzające uprawnienia lub ograniczające obowiązki po stronie pracowniczej obejmują wszystkich świadczących pracę na rzecz określonego pracodawcy. ${ }^{25}$ Sąd Najwyższy w wyroku z dnia

\footnotetext{
19 „Prawo Pracy” 2002, nr 7-8, s. 49.

20 Wyrok SN z 10 października 2007 r., II PK 38/07, OSNP 2008, nr 21-22, poz. 313.

21 IPK 174/11, niepublikowany.

22 Zob. L. Florek, Ustawa i umowa w prawie pracy, Warszawa 2010, s. 161 i n.; Z. Hajn, Zbiorowe prawo pracy. Zarys systemu, Warszawa 2013, s. 150.

23 Zob. I. Sierocka, Pracownicze programy emerytalne, Białystok 2010, s. 33 i n.

24 Zob. L. Garlicki, Komentarz do art. 32, (w:) Konstytucja Rzeczypospolitej Polskiej. Komentarz, t. III, Warszawa 2003, s. 17.

25 Zob. W. Sanetra, Wykładnia przepisów układu zbiorowego pracy - problem ciągle aktualny, PiZS 2007, nr 9, s. 8 W. Sanetra, Komentarz do art. 9, (w:) J. Iwulski, W. Sanetra, Kodeks pracy. Komentarz, Warszawa 2011, s. 86.
} 
12 września $2006 \mathrm{r}^{26}$ orzekł, że postanowienia zakładowego układu zbiorowego pracy, przyznające $\mathrm{w}$ okresie gwarantowanego zatrudnienia wyższą odprawę pracownikowi zwalnianemu z pracy później niż pracownikowi zwalnianemu wcześniej, narusza zasadę równego traktowania w zatrudnieniu (art. $11^{2} \mathrm{i}$ art. $18^{3 \mathrm{a}} \mathrm{k}$.p.). Pracownikowi zwalnianemu z pracy wcześniej przysługuje w takiej sytuacji odprawa w wysokości nie niższej niż pracownikowi zwalnianemu później (art. 9 § 4 k.p.).

Mając na względzie powyższe okoliczności należy przyjąć, że ograniczenia przewidziane w $\S 31$ ust. 8 p.u.z.p. jako naruszające zasadę równości nie obowiązują. Z roszczeniem o wypłatę nagrody wystąpić mogą zatem pracownicy zwalniani w związku z przejściem na emeryturę lub rentę z tytułu niezdolności do pracy, którym do osiągnięcia 50 lat pracy brakuje nie więcej niż 12 miesięcy.

Dodatki do wynagrodzenia zasadniczego przewidziane w p.u.z.p. (dodatek za pracę w warunkach szkodliwych i uciążliwych, dodatek stażowy, nagroda jubileuszowa, premie) są składnikami o charakterze fakultatywnym. Zarówno w ustawie o ochronie przyrody, jak i w kodeksie pracy nie ma bowiem regulacji zobowiązujących pracodawcę do ich wypłaty. Składniki te należy ponadto uznać za świadczenia o charakterze roszczeniowym, co oznacza, że pracownik spełniający przesłanki warunkujące nabycie prawa do określonego dodatku może domagać się od pracodawcy jego wypłaty w wysokości ustalonej w układzie zbiorowym. W razie odmowy pracownik uprawniony jest do wystąpienia z powództwem do sądu pracy. Roszczeniowość w przypadku nagrody jubileuszowej powoduje, że świadczenie to w istocie stanowi premię z tytułu długoletniej pracy. ${ }^{27}$

\section{Wynagrodzenie za czas niezdolności do pracy wskutek choroby}

Generalnie pracownik niezdolny do pracy wskutek choroby uprawniony jest do świadczeń z ubezpieczenia społecznego. Podstawową rolę w tym zakresie odgrywa zasiłek chorobowy. ${ }^{28} \mathrm{~W}$ pewnym stopniu ryzykiem socjalnym obciążony jest także pracodawca. Na podstawie art. $92 \S 1$ k.p. za pierwsze 33 dni w roku kalendarzowym tej niezdolności, a w odniesieniu do osób, które ukończyły 50 lat - za pierwsze 14 dni niezdolności, jest on zobowiązany do wypłaty wynagrodzenia w wysoko-

26 I PK 87/06, OSNP 2007, nr 17-18, poz. 246.

27 Zob. T. Liszcz, Prawo pracy, Warszawa 2009, s. 290; M. Seweryński, Wynagrodzenie za pracę. Pojęcie, regulacja, ustalenie, Warszawa 1981, s. 90-91.

28 Na temat zasiłku chorobowego zob. M. Gersdorf, M. Iżycka-Rączka, J. Jagielski, K. Rączka, Komentarz do ustawy o świadczeniach pieniężnych z ubezpieczenia społecznego w razie choroby i macierzyństwa. Zasiłek chorobowy, rehabilitacyjny, wyrównawczy, porodowy, macierzyński, opiekuńczy, Warszawa 2000; I. Jędrasik-Jankowska, Świadczenia pieniężne za czas niezdolności do pracy z powodu choroby, Warszawa 1996; I. Jędrasik-Jankowska, Ubezpieczenia społeczne, tom 3, Ubezpieczenia chorobowe. Ubezpieczenia wypadkowe, Warszawa 2003; A. Rzetecka-Gil, Ustawa o świadczeniach pieniężnych z ubezpieczenia społecznego w razie choroby i macierzyństwa. Komentarz, Warszawa 2009; Ł. Prasołek, (w:) Społeczne ubezpieczenia wypadkowe i chorobowe. Komentarz, M. Gersdorf, B. Gudowska (red.), Warszawa 2012. 
ści $80 \% .{ }^{29}$ Po upływie wskazanych terminów utratę zarobków rekompensuje zasiłek chorobowy przewidziany w ustawie z dnia 25 czerwca 1999 r. o świadczeniach pieniężnych z ubezpieczenia społecznego w razie choroby i macierzyństwa. ${ }^{30}$ Nieco inaczej rzecz się ma w przypadku pracowników objętych postanowieniami p.u.z.p.

Według $\S 34$ ust. 1 p.u.z.p. za czas niezdolności pracownika do pracy wskutek: a) choroby lub odosobnienia $\mathrm{w}$ związku z chorobą zakaźną - trwającej łącznie do 33 dni w ciągu roku kalendarzowego, a w przypadku pracownika, który ukończył 50. rok życia - trwającej łącznie do 14 dni w ciągu roku kalendarzowego - pracownik ma prawo do: $80 \%$ wynagrodzenia, jeżeli okres jego zatrudnienia wynosi mniej niż 15 lat, 100\% wynagrodzenia, jeżeli okres jego zatrudnienia wynosi co najmniej 15 lat. W stosunku do osób świadczących pracę w parkach narodowych przez okres krótszy niż 15 lat strony układowe powtórzyły zatem zasady obejmujące ogół zatrudnionych. Korzystniej natomiast uregulowano sytuację pracowników pozostających w zatrudnieniu przez okres co najmniej 15 lat. Ci ostatni upoważnieni są do wynagrodzenia w pełnej kwocie.

Zgodnie z treścią art. 6 ustawy zasiłkowej co do zasady zasiłek chorobowy przysługuje ubezpieczonemu, który w czasie trwania ubezpieczenia stał się niezdolny do pracy z powodu choroby lub wystąpiły inne zdarzenia traktowane przez ustawodawcę $\mathrm{w}$ sposób równorzędny $\mathrm{z}$ chorobą. Wśród nich $\mathrm{w}$ art. 6 ust. 2 ustawy zasiłkowej wymienia się niemożność wykonywania pracy: 1) w wyniku decyzji wydanej przez właściwy organ albo uprawniony podmiot na podstawie przepisów o zapobieganiu oraz zwalczaniu zakażeń i chorób zakaźnych u ludzi; 2) z powodu przebywania w: a) stacjonarnym zakładzie lecznictwa odwykowego w celu leczenia uzależnienia alkoholowego, b) stacjonarnym zakładzie opieki zdrowotnej w celu leczenia uzależnienia od środków odurzających lub substancji psychotropowych; 3) wskutek poddania się niezbędnym badaniom lekarskim przewidzianym dla kandydatów na dawców komórek, tkanek i narządów.

W omawianym układzie zbiorowym pracy brak jest postanowień co do leczenia odwykowego. Pojawia się zatem pytanie, czy pracownik przebywający w zakładzie lecznictwa odwykowego uprawniony jest do wypłaty gwarancyjnej. W mojej ocenie odpowiedź na postawione pytanie powinna być twierdząca. W myśl § 34 ust. 4 lit. b. analizowanego układu wynagrodzenie gwarancyjne przysługuje w przypadkach, w których pracownik zachowuje prawo do zasiłku chorobowego. Skoro w czasie pobytu w zakładzie leczenia odwykowego pracownik uprawniony jest do tego rodzaju świadczenia, to mając na względzie postanowienia z $\S 34$ ust. 4 lit. b tego

29 Na temat wynagrodzenia za czas niezdolności do pracy zob. A. Kosut, Wynagrodzenie za czas niezdolności do pracy z powodu choroby (wybrane zagadnienia, PiZS 2003, nr 1; Ł. Pisarczyk, Wynagrodzenie czy zasiłek w sprawie świadczeń za czas niezdolności do pracy, (w:) Wynagrodzenie za pracę w warunkach społecznej gospodarki rynkowej i demokracji, W. Sanetra (red.), Warszawa 2009; A. Napiórkowska, Wynagrodzenie za pracę w okresie niezdolności do pracy z powodu choroby, (w:) Wynagrodzenie za pracę w warunkach społecznej gospodarki rynkowej i demokracji, W. Sanetra (red.), Warszawa 2009. 
układu, należałoby przyjąć, że także w tym przypadku upoważniony jest do zasiłku chorobowego.

Zatrudniony nieobecny w pracy z powodu choroby lub odosobnienia w związku $\mathrm{z}$ chorobą zakaźną $\mathrm{w}$ okresie od 34 dnia niezdolności do pracy, a w przypadku pracownika, który ukończył 50. rok życia - w okresie od 15 dnia niezdolności do pracy - otrzymuje od pracodawcy świadczenie uzupełniające w wysokości stanowiącej różnicę między kwotą odpowiadającą 100\% wynagrodzenia a kwotą należnego zasiłku chorobowego. $Z$ uprawnienia w tym zakresie korzysta pracownik legitymujący się co najmniej 15-letnim ogólnym stażem pracy ( $\$ 34$ ust. 1 lit. b p.u.z.p.). Przepis ten oznacza, że pracownicy parków narodowych mający co najmniej 15-letni okres pracy poza zasiłkiem chorobowym wypłacanym przez instytucję ubezpieczeniową uprawnieni są do świadczenia uzupełniającego. Wobec braku zastrzeżeń co do długości wypłaty tego świadczenia należy przyjąć, że świadczenie uzupełniające wypłacane jest do końca okresu zasiłkowego. W konsekwencji pracownikom, którzy nie ukończyli 50 lat pracodawca wypłaca świadczenie uzupełniające w okresie od 34. do 182. lub 270. dnia niezdolności do pracy wskutek choroby, natomiast pracownikom starszym wypłata dodatku rozpoczyna się 15. dnia tej niezdolności.

Miesięczny zasiłek chorobowy co do zasady wynosi $80 \%$ podstawy wymiaru zasiłku, w przypadku osób poddawanych leczeniu szpitalnemu świadczenie to wypłacane jest $\mathrm{w}$ wysokości $70 \%$ podstawy wymiaru zasiłku. Nieco inaczej w odniesieniu do pracowników, którzy ukończyli 50. rok życia. W okresie od 15. do 33. dnia niezdolności do pracy w roku kalendarzowym w okresie pobytu w szpitalu uprawnieni są do zasiłku w wysokości $80 \%$ podstawy wymiaru (art. 11 ust. 1 ustawy zasiłkowej).

Zgodnie z postanowieniami omawianego układu do wynagrodzenia w wysokości 100\% upoważnieni są, poza osobami zatrudnionymi przez okres co najmniej 15 lat, także pracownicy poddający się niezbędnym badaniom lekarskim, przewidzianym dla kandydatów na dawców komórek, tkanek i narządów oraz osoby poddające się zabiegowi pobrania komórek, tkanek i narządów. Według uregulowań kodeksu pracy z uprawnienia w tym względzie korzystają także pracownicy, których niezdolność do pracy powstała $\mathrm{w}$ wyniku wypadku $\mathrm{w}$ drodze do pracy lub $\mathrm{z}$ pracy albo choroba przypada w okresie ciąży. Mimo braku w p.u.z.p. wyraźnego odesłania do regulacji kodeksowych, nie budzi wątpliwości, że zasady przewidziane w art. $92 \S 1$ pkt 2 k.p. w pełnym zakresie obejmują pracowników zatrudnionych w parkach narodowych objętych ponadzakładowym układem zbiorowym pracy.

Przy ustalaniu okresu zatrudniania wpływającego na wysokość wynagrodzenia za czas choroby stosuje się zasady dotyczące dodatku stażowego. W konsekwencji uwzględnienia $\mathrm{w}$ tym zakresie wymaga nie tylko tzw. ogólny staż pracy, ale także okresy prowadzenia działalności gospodarczej.

Wynagrodzenie za czas niezdolności do pracy wskutek choroby oblicza się według zasad obowiązujących przy ustalaniu podstawy zasiłku chorobowego. Uwzględ- 
nienia w tym zakresie wymaga wynagrodzenie wypłacane przez pracodawcę, od którego ustalono składkę na ubezpieczenie społeczne. Podstawą wyliczenia zasiłku jest przeciętne wynagrodzenie pracownika za okres 6 miesięcy poprzedzających miesiąc, w którym powstało prawo do zasiłku. Gdy wysokość wynagrodzenia pracownika ulega znacznemu wahaniu, podstawę obliczenia wymiaru zasiłku stanowi przeciętne wynagrodzenie za okres 12 miesięcy poprzedzających miesiąc powstania prawa do zasiłku. Zasiłek za każdy dzień niezdolności do pracy stanowi 1/30 tak obliczonego wynagrodzenia. Wynagrodzenie gwarancyjne wypłacane jest za każdy dzień niezdolności do pracy, nie wyłączając dni wolnych od pracy.

W układzie zastrzega się, że wynagrodzenie gwarancyjne nie przysługuje w przypadkach, w których pracownik nie ma prawa do zasiłku chorobowego. Zgodnie $\mathrm{z}$ uregulowaniami ustawy zasiłkowej pracownik nabywa prawo do zasiłku chorobowego po 30 dniach nieprzerwanego ubezpieczenia chorobowego. Wymóg „nieprzerwanego ubezpieczenia” nie ma charakteru bezwzględnego. Do okresu tego wlicza się bowiem poprzednie okresy ubezpieczenia, jeśli przerwa między nimi nie przekroczyła 30 dni lub była spowodowana urlopem wychowawczym, urlopem bezpłatnym albo odbywaniem czynnej służby wojskowej przez żołnierza niezawodowego.

Od pierwszego dnia ubezpieczenia chorobowego prawo do zasiłku chorobowego przysługuje: 1) absolwentom szkół lub szkół wyższych, którzy zostali objęci ubezpieczeniem chorobowym lub przystąpili do ubezpieczenia chorobowego w ciągu 90 dni od dnia ukończenia szkoły lub uzyskania dyplomu ukończenia studiów wyższych; 2) jeżeli niezdolność do pracy spowodowana została wypadkiem w drodze do pracy lub z pracy; 3) ubezpieczonym obowiązkowo, którzy mają wcześniejszy co najmniej 10-letni okres obowiązkowego ubezpieczenia chorobowego; 4) posłom i senatorom, którzy przystąpili do ubezpieczenia chorobowego w ciągu 90 dni od ukończenia kadencji.

Pracownik nie jest uprawniony do zasiłku chorobowego, a w ślad za tym do wynagrodzenia gwarancyjnego za okresy niezdolności do pracy przypadającej w czasie: urlopu bezpłatnego, urlopu wychowawczego, tymczasowego aresztowania lub odbywania kary pozbawienia wolności, z wyjątkiem przypadków, w których prawo do zasiłku wynika z ubezpieczenia chorobowego osób wykonujących odpłatnie pracę na podstawie skierowania do pracy w czasie odbywania kary pozbawienia wolności lub tymczasowego aresztowania. $Z$ wyłączeniem prawa do zasiłku chorobowego mamy do czynienia także w sytuacji, gdy niezdolność do pracy została spowodowana w wyniku umyślnego przestępstwa lub wykroczenia popełnionego przez tego ubezpieczonego.

Zatrudnionemu, którego niezdolność do pracy spowodowana została nadużyciem alkoholu, zarówno zasiłek chorobowy, jak i wynagrodzenie gwarancyjne nie przysługuje za okres pierwszych 5 dni tej niezdolności. 
Za cały okres zwolnienia lekarskiego prawo do wymienionych świadczeń traci pracownik wykonujący w okresie orzeczonej niezdolności do pracy pracę zarobkową lub wykorzystujący zwolnienie od pracy w sposób niezgodny z celem tego zwolnienia, ${ }^{31}$ bądź posługujący się sfałszowanym zaświadczeniem lekarskim.

Sąd Najwyższy w wyroku z 5 czerwca 2008 r. ${ }^{32}$ orzekł, że o zakwalifikowaniu wykonywania określonych czynności jako „pracy” nie decyduje charakter stosunku prawnego, na podstawie którego są one wykonywane, ale rodzaj tych czynności. W art. 17 ust. 1 ustawy zasiłkowej chodzi nie tylko o wykonywanie pracy na podstawie stosunku pracy lub innego stosunku zatrudnienia, ale także o wykonywanie różnych czynności na podstawie różnych stosunków prawnych o charakterze cywilnoprawnym, a także prowadzenie własnej działalności gospodarczej, samozatrudnienie. ${ }^{33}$

\section{Podsumowanie}

Mając na względzie treść ponadzakładowego układu zbiorowego pracy wynegocjowanego w 2013 r. należy stwierdzić, że uprawnienia pracowników parków narodowych w sferze płacowej określone zostały w sposób korzystny dla zatrudnionych. Dotyczy to zwłaszcza postanowień regulujących świadczenia przysługujące pracownikom w okresie niezdolności do pracy wskutek choroby. W przeciwieństwie do ogółu zatrudnionych pracownicy, którzy legitymują się co najmniej 15-letnim okresem aktywności zawodowej, poza zasiłkiem chorobowym wypłacanym przez ZUS, uprawnieni są do świadczenia uzupełniającego finansowanego ze środków pracodawcy. W konsekwencji w okresie pobierania świadczenia ubezpieczeniowego ich sytuacja materialna nie ulega w zasadzie pogorszeniu.

Uwagę zwracają także postanowienia określające wynagrodzenie gwarancyjne za czas przestoju spowodowanego warunkami atmosferycznymi. Zgodnie z treścią układu pracownicy wykonujący prace uzależnione od warunków atmosferycznych upoważnieni są do wynagrodzenia, o ile przestój został spowodowany: temperaturą poniżej minus $20^{\circ} \mathrm{C}$ utrzymującą się w ciągu całego dnia pracy, burzami śnieżnymi oraz silnymi wichurami, deszczami lub gołoledzią (§ 26).

Zob. wyrok SN z dnia 9 czerwca 2009 r., II UK 403/08, LEX nr 523551; wyrok SN z dnia 4 listopada 2009 r. I UK 140/09, LEX nr 564767; wyrok SN z dnia 25 kwietnia 2013 r. I UK 606/12, LEX nr 1391152.

32 III UK 11/08, OSNP 2009, nr 21-22, poz. 292.

33 Zob. wyrok SN z dnia 20 stycznia 2005 r., I UK 154/04, OSNP 2005, nr 19, poz. 307; wyrok SN z dnia 5 kwietnia 2005 r., I UK 370/04, OSNP 2005, nr 21, poz. 342; wyrok SN z dnia 9 października 2006 r., II UK 44/06, OSNP 2007, nr 19-20, poz. 295; wyrok SN z dnia 11 grudnia 2007 r., I UK 145/07, OSNP 2009, nr 1-2, poz. 28; wyrok SN z dnia 6 lutego 2008, II UK 10/07, LEX nr 448871; wyrok SN z dnia 3 października 2008 r., II UK 26/08, LEX nr 513018; wyrok SN z dnia 4 kwietnia 2012 r. II UK 186/11, LEX nr 1216851; wyrok SN z dnia 6 lutego 2014 r., II UK 274/13, LEX nr 1455233. 
Osoby świadczące pracę w parkach narodowych uprawnione są ponadto do „trzynastki” na zasadach określonych w ustawie z dnia 12 grudnia 1997 r. o dodatkowym wynagrodzeniu rocznym dla pracowników jednostek sfery budżetowej. ${ }^{34}$

Wątpliwości budzą natomiast postanowienia układowe określające zasady wypłat nagród jubileuszowych osobom, które do dnia rozwiązania stosunku pracy z powodu przejścia na emeryturę lub rentę z tytułu niezdolności do pracy nie osiągnęły pełnego stażu w wymiarze 50 lat. Wyłączenie tych osób spod mechanizmów przewidzianych w $\S 31$ ust. 8 , w moim przekonaniu, nosi znamiona dyskryminacji. 
REMUNERATION OF NATIONAL PARK EMPLOYEES

The author discusses the problems relating to the remuneration of employees of national parks. The cogitation is focused on the provisions of the supra-corporate collective labour agreement concluded in 2013. In accordance with the provisions of the agreement, the person performing the work in national parks shall be entitled, in addition to the basic salary, to allowances among which are mentioned: seniority allowance, allowance for work in conditions hazardous to health or onerous, jubilee awards, bonuses and additional annual remuneration. The agreement regulates in particular issues regarding the remuneration for the period of incapacity for work due to illness, which is referred to as a guarantee payment. The analysis of the agreement provisions aims to determine whether the collective labour agreement covering employees of national parks conforms to the labour law, particularly with respect to the acquisition and the amount of the individual components of the remuneration.

Keywords:collective labour agreement, basic salary, jubilee award, guarantee payment 